\title{
- Original Contribution \\ INTERACTION OF VIABLE GROUP A STREPTOCOCCI AND HYDROGEN PEROXIDE IN KILLING OF VASCULAR ENDOTHELIAL CELLS
}

\author{
ISAAC GINSBURG* and JAMES VARANI $\dagger$ \\ *Department of Oral Biology, Hadassah School of Dental Medicine, Hebrew University, Jerusalem, Israel; \\ and †Department of Pathology, The University of Michigan Medical School, Ann Arbor, MI 48109, USA
}

(Received 6 August 1992; Revised 1 December 1992; Accepted 3 December 1992)

\begin{abstract}
Previous studies have shown that the streptococcal hemolysin, streptolysin S, is capable of interacting with hydrogen peroxide $\left(\mathrm{H}_{2} \mathrm{O}_{2}\right)$ to injure vascular endothelial cells (Free Radic. Biol. Med. 7:369-376; 1989). To extend these observations, intact group A streptococci (strain 203S) were examined for ability to injure endothelial cells alone and for ability to injure the same cells in the presence of sublethal concentrations of $\mathrm{H}_{2} \mathrm{O}_{2}$ (generated from glucose/glucose oxidase). While neither control bacteria nor bacteria that had been pretreated with poly-L-histidine to render them cationic were cytotoxic to endothelial cells by themselves under the conditions of the experiment, endothelial cells were injured by combinations of streptococcal cells and sublytic amounts of $\mathrm{H}_{2} \mathrm{O}_{2}$. Taken together, these data suggest that the sequelae which often occur following primary infection with group A streptococci may be the result of a combined assault of host inflammatory cells and the invading bacteria on the vascular lining cells of the host.
\end{abstract}

Keywords-Group A streptococci, Hydrogen peroxide, Endothelial cells, Poly-L-histidine, Cationic peptide, Cytotoxicity, Streptolysin S, Free radicals

\section{INTRODUCTION}

Neutrophils play a critical role in the pathogenesis of acute inflammatory diseases such as adult respiratory distress syndrome (ARDS). ${ }^{1,2}$ A role for neutrophils in chronic inflammatory conditions, including some glomerulonephropathies ${ }^{3,4}$ and certain forms of arthritis, ${ }^{5}$ has also been shown. In experimental animals, prior neutrophil depletion greatly attenuates subsequent injury resulting from immune complex deposition in lung, kidney, or skin. ${ }^{6-8}$ In addition, treatment with catalase affords a high degree of protection in the lungs and kidney, ${ }^{6,7,9}$ as do scavengers of oxygen radicals $^{9}$ and iron chelators. ${ }^{9}$ Based on these types of findings, it has been assumed that neutrophil-mediated tissue injury is largely a result of oxygen radical generation by activated neutrophils. In vitro studies of vascular endothelial cell injury by activated neutrophils also demonstrate a critical role for leukocyte-derived oxidants. $^{10-13}$

Address correspondence to: James Varani, PhD, Department of Pathology, The University of Michigan Medical School, 1301 Catherine Road, Box 0602, Ann Arbor, MI 48109-0602.
While neutrophil-derived oxidants are clearly important for cell and tissue injury during acute inflammation, the inflammatory nidus contains a complex mixture of substances capable of damaging cells and tissues. In addition to neutrophil-derived oxidants, contents of neutrophil granules are also released at sites of inflammation. Among the granule contents that are capable of injuring tissues are potent neutral and acidic proteases, other hydrolytic enzymes such as phospholipase $\mathrm{A} 2$ and phospholipase $\mathrm{C}$, and small cationic proteins. ${ }^{14,15}$ Products of other inflammatory cells including various cytokines ${ }^{16,17}$ may also contribute to the developing inflammation. In cases of microbial infection, products of these cells may contribute as well. ${ }^{18-20}$ Undoubtedly, the inflammatory lesion reflects the contributions of many different effector molecules.

While each of the various soluble inflammatory mediators may contribute to the pathogenesis of the inflammatory response by their independent activities, we have shown in previous studies that many of these same mediators synergize with neutrophil hydrogen peroxide $\left(\mathrm{H}_{2} \mathrm{O}_{2}\right)$ to injure vascular endothelial cells. $^{21-24}$ Among bacterial products, we found that 
solubilized streptolysin S from group A streptococci (though not streptolysin $O$ from the same cells) dramatically enhanced endothelial cell killing by $\mathrm{H}_{2} \mathrm{O}_{2},{ }^{22,23} \mathrm{On}$ the basis of these data, we have speculated that the pathogenesis of some streptococcal sequelae may result from streptococci binding to vascular endothelial cells and provoking the destruction of the vascular lining by neutrophils as they attempt to clear the bacteria from vascular lining. To obtain further support for this idea, experiments were conducted in which intact streptococcal cells were used in place of soluble components. We report here that intact group A streptococcal cells containing streptolysis $\mathrm{S}$ synergize with $\mathrm{H}_{2} \mathrm{O}_{2}$ in provoking endothelial cell injury.

\section{MATERIALS AND METHODS}

\section{Endothelial cells}

Rat pulmonary artery endothelial cells available from previous studies in our laboratory ${ }^{21,25}$ were used. The cells were originally isolated from the pulmonary vasculature by perfusion of microcarrier beads into the vessels and subsequent retrieval of the beads and endothelial cells by retrograde perfusion. Upon isolation, the cells exhibited the typical cobblestone morphology of endothelial cells. They were positive for factor VIII by immunofluorescence, bound acetylated low-density lipoprotein, and had high levels of angiotensin-converting enzyme (ACE) $\left(3.2 \times 10^{4}-1.9\right.$ $\times 10^{5}$ molecules/cell) as measured with the synthetic substrate, ${ }^{3} \mathrm{H}$-Benzoyl-phe-ala-pro. The cells were maintained in monolayer culture using minimal essential medium of Eagle with Earle's salts (MEM) supplemented with $10 \%$ fetal bovine serum, 100 units $/ \mathrm{ml}$ of penicillin, and $100 \mu \mathrm{g} / \mathrm{ml}$ of streptomycin as culture medium. They were passaged by trypsinization as needed. Growth was at $37^{\circ} \mathrm{C}$ and $5 \% \mathrm{CO}_{2}$. Stocks were kept frozen in liquid $\mathrm{N}_{2}$. All experiments were conducted on cells passaged less than 34 times since isolation. Throughout the course of the studies, the endothelial cells maintained their cobblestone morphology and levels of ACE activity.

\section{Streptococcal cells}

Group A streptococci (strain 203S) were obtained from the American Type Culture Collection (Rockville, MD). Streptococci were cultivated in brainheart infusion broth to the end of the logarithmic phase of growth. The bacterial cells were washed several times with isotonic saline and resuspended to a density of $10 \mathrm{OD}$ units $/ \mathrm{ml}$ at $550 \mathrm{~nm}$. Twofold dilutions of the streptococcal suspension in a final volume of $0.5 \mathrm{ml}$ were performed. To each dilution tube was added $1 \mathrm{mg} / \mathrm{ml}$ of glucose, $1 \mathrm{mg} / \mathrm{ml}$ of $\mathrm{MgSO}_{4} \cdot 7 \mathrm{H}_{2} \mathrm{O}$, and $1 \mathrm{mg} / \mathrm{ml}$ of cysteine free base. Under these conditions, the cell-bound hemolysin is activated and is capable of lysing red blood cells in the absence of a cellfree phase. Previous studies have characterized red cell lysis by the cell-bound hemolysin and demonstrated that the cell-bound hemolysin is indistinguishable from streptolysin $\mathrm{S}^{26,27}$

To facilitate the adherence of the streptococci possessing the cell-bound hemolysin to the endothelial cells and the delivery of the hemolysin to membrane targets, we have cationized the streptococcal suspension. To $1 \mathrm{ml}$ of saline suspension of streptococci (10 OD units at $550 \mathrm{~nm}), 25 \mu \mathrm{g} / \mathrm{ml}$ of poly-L-histidine (mol wt 23,000) was added for $5 \mathrm{~min}$ at $37^{\circ} \mathrm{C}$. The bacterial suspension was then washed once with $10 \mathrm{ml}$ of saline and resuspended to the original volume with saline. Such cationized streptococci did not lose their cell-bound hemolytic activity. Following addition of the cationized streptococci or untreated control streptococci to the endothelial cell monolayers, the plates were centrifuged for $2 \mathrm{~min}$ at $400 \mathrm{rpm}$. Microscopic examination showed that almost all the cationized streptococci avidly adhered to the surface of the endothelial cells and could not be removed by washing.

\section{Streptolysin $S$}

Soluble streptolysin $\mathrm{S}$ was prepared from group A streptococci as previously described. ${ }^{26,27}$ Hemolytic activity of each preparation was verified using red blood cell lysis as an indicator.

\section{$\mathrm{H}_{2} \mathrm{O}_{2}$}

$\mathrm{H}_{2} \mathrm{O}_{2}$ was generated from a mixture of glucose and glucose oxidase (GO). To generate $\mathrm{H}_{2} \mathrm{O}_{2}, 0.5-2$ units/ $\mathrm{ml}$ of $\mathrm{GO}$ were used. This amount of $\mathrm{GO}$ was able to generate $500-1000 \mathrm{nmol}$ of $\mathrm{H}_{2} \mathrm{O}_{2}$ in $15 \mathrm{~min}$ in Hank's balanced salt solution (HBSS) $\left(37^{\circ} \mathrm{C}, \mathrm{pH} 7.3\right)$. The method of Thurman et al. ${ }^{28}$ employing ferrous ammonium sulfate and sodium thiocyanate was employed to quantitate $\mathrm{H}_{2} \mathrm{O}_{2}$ production. Both $\mathrm{HBSS}$ and MEM contain $1 \mathrm{mg} / \mathrm{ml}$ of glucose, and glucose concentration is limiting. When $\mathrm{H}_{2} \mathrm{O}_{2}$ concentrations were measured after 30 and $60 \mathrm{~min}$, no net increase in $\mathrm{H}_{2} \mathrm{O}_{2}$ was seen over that seen at the 15 -min timepoint.

\section{Cytotoxicity assay}

Cytotoxicity was assessed using a ${ }^{51} \mathrm{Cr}$-release assay as described previously. ${ }^{13,21,23-25}$ Briefly, endothelial cells were harvested by trypsinization, resuspended at 
$1.0 \times 10^{5}$ cells $/ \mathrm{ml}$ in MEM supplemented with $10 \%$ fetal bovine serum and $1 \mu \mathrm{Ci} / \mathrm{ml}$ of $\mathrm{Na}^{51} \mathrm{CrO}_{4}$, and seeded into the wells of 24-well plates $(1 \mathrm{ml} /$ well $)$. The cells were incubated at $37^{\circ} \mathrm{C}$ and $5 \% \mathrm{CO}_{2}$ until the cells formed a confluent monolayer (usually 1 day). When the cells reached confluency, the wells were washed three times to remove unbound radioactivity. One milliliter of serum-free MEM containing $200 \mu \mathrm{g} /$ $\mathrm{ml}$ bovine serum albumin was then added per well, and the cells were treated with GO alone or in combination with intact streptococci or with soluble streptococcal products. The cultures were further incubated for $2 \mathrm{~h}$ (unless otherwise stated) at $37^{\circ} \mathrm{C}$ and $5 \%$ $\mathrm{CO}_{2}$. At the end of the incubation period, the cells were observed under phase-contrast microscopy for morphological changes characteristic of injury. The amount of radioactivity released into the culture medium was simultaneously determined. For this, 0.8 $\mathrm{ml}$ of culture fluid was removed from the wells and centrifuged at $2000 \mathrm{rpm}$ to remove unattached cells. The radioactivity released into the supernatant fluid was quantified using a gamma counter. In all experiments, the amount of radioactivity released in response to treatment was compared to the amount released in cultures incubated with buffer alone (spontaneous release) and in cultures treated with $2 \%$ Triton $\mathrm{X}-100$ (total release). The data, which are reported as percent killed, refer to the percentage of total ${ }^{31} \mathrm{Cr}$ released from each group, including the total group, as compared to the amount released from Triton X-100treated cells.

Previous studies have demonstrated a close correlation between ${ }^{51} \mathrm{Cr}$ release and lethal injury in rat pulmonary artery endothelial cells. ${ }^{24,25}$ To confirm lethal injury, nonlabeled endothelial cells were treated in parallel with ${ }^{51} \mathrm{Cr}$-labeled cells in certain experiments. Following exposure to GO and streptococcal cells, the endothelial cells were harvested and replated in complete culture medium (MEM supplemented with $10 \%$ fetal bovine serum). Four hours later, the number of cells that had reattached and spread was determined. Cells unable to reattach and spread were counted as nonviable. ${ }^{24,25}$

\section{RESULTS}

Endothelial cell injury produced by combinations of $G O$ and soluble streptolysin $S$

We have previously shown that increasing amounts of reagent $\mathrm{H}_{2} \mathrm{O}_{2}$ or $\mathrm{GO}$ are capable of inducing irreversible injury to cultured rat pulmonary artery endothelial cells. ${ }^{23}$ It was shown in the same study that soluble streptolysin $S$ by itself does not kill the same cells at concentrations as high as 250 hemolytic
Table 1. Interaction of Streptolysin S and GO in Endothelial Cell Killing

\begin{tabular}{lc}
\hline Treatment Group & Percent Killed \\
\hline None & $5 \pm 1$ \\
GO $(0.2$ units $/ \mathrm{mL})$ & $6 \pm 1$ \\
Streptolysin S $(50$ hemolytic units $/ \mathrm{mL})$ & $9 \pm 2$ \\
GO + Streptolysin S & $55 \pm 5$ \\
$\quad$ + catalase $(1800$ units) & $10 \pm 3$ \\
$\quad$ trypan blue $(50 \mu \mathrm{g} / \mathrm{mL})$ & $7 \pm 5$ \\
\hline
\end{tabular}

Values shown are means \pm differences between individual values and means based on duplicate samples in a single experiment. The experiment was conducted three times with similar results.

units per milliliter but is capable of synergizing with low concentrations of $\mathrm{H}_{2} \mathrm{O}_{2}$ to cause lethal injury. To confirm that the group A streptococci used in the present study express a similar toxin, purified streptolysin $S$ from bacterial strain $203 \mathrm{~S}$ was incubated in increasing amounts with rat pulmonary artery endothelial cells in the presence and absence of glucose oxidase. Consistent with past results, ${ }^{23}$ combinations of GO and streptolysis $S$ which were non-toxic by themselves synergized to produce a significant degree of lethal injury (Table 1). It can also be seen in Table 1 that incubation of the GO-streptolysin S mixture with either catalase or trypan blue (a potent inhibitor of streptolysin $\mathrm{S}$ hemolytic activity $^{29}$ ) completely blocked cell injury.

Interaction between group A streptococci and $\mathrm{H}_{2} \mathrm{O}_{2}$ in endothelial cell injury

In the next series of experiments, group A streptococci were harvested, washed in saline, and divided into two groups. One group of cells was further treated with poly-L-histidine to impart a positive charge on the cell surface as described in the Materials and Methods section. The other group was left as control. Following this, increasing amounts of the control streptococci and the poly-L-histidine-treated streptococci were added to endothelial cell monolayers. The plates containing the endothelial cells and bacteria were then centrifuged at $400 \mathrm{rpm}$ for $2 \mathrm{~min}$ to facilitate the interaction between the two cell types. Glucose oxidase $(0.2 \mathrm{U} / \mathrm{ml})$ was added and the cells incubated for an additional $2 \mathrm{~h}$, after which injury was measured. As shown in Fig. 1, neither untreated streptococci nor poly-L-histidine-treated cells were directly injurious to the target endothelial cells over the 2-h time period. However, both the untreated bacteria and the bacteria expressing the cationic charge on their surface were capable of synergizing with low concentrations of GO to cause injury. It can also be 


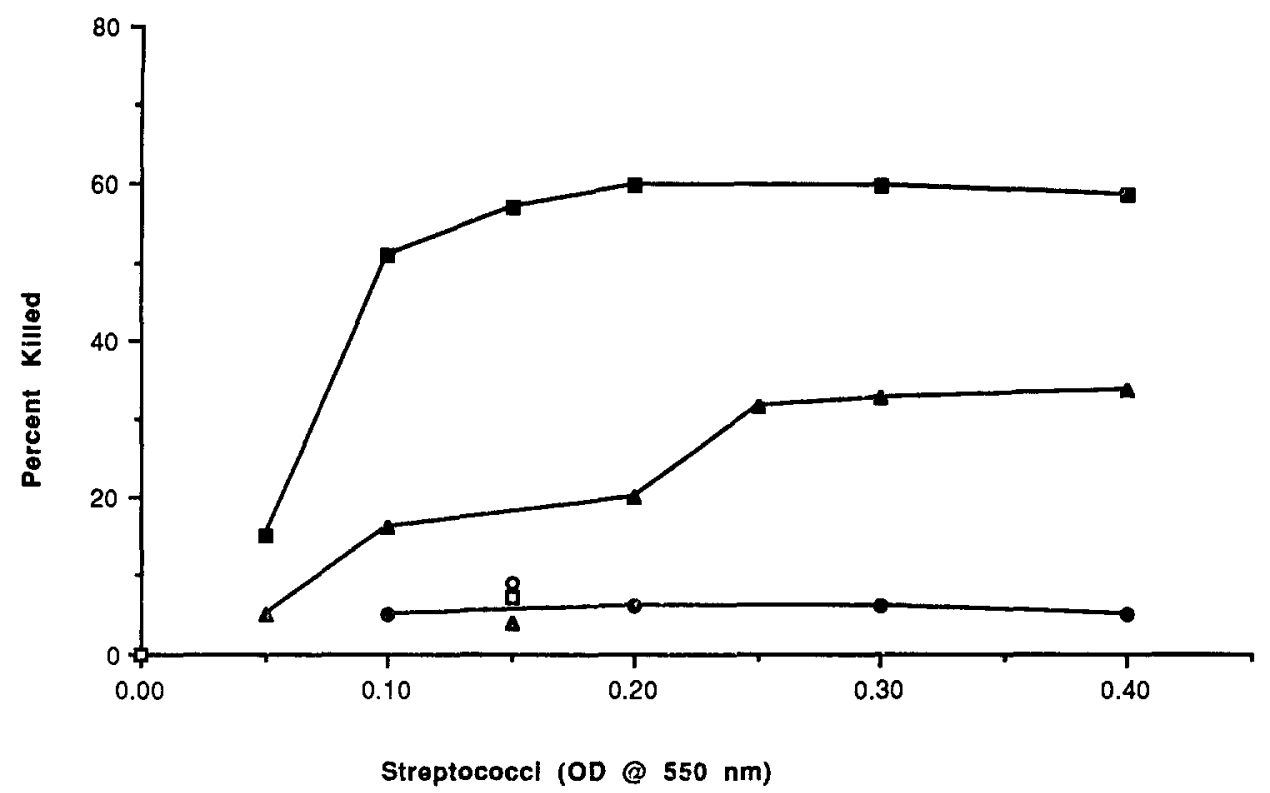

Fig. 1. Interaction of intact group A streptococci and GO to injure vascular endothelial cells. Increasing amounts of streptococcal cells along with a constant amount of $G O(0.2$ units $/ \mathrm{ml})$ were incubated for $2 \mathrm{~h}$ with monolayers of rat pulmonary artery endothelial cells. At the end of the incubation period, injury was measured as ${ }^{51} \mathrm{Cr}$ release, as described in the Materials and Methods section. Values shown represent averages based on duplicate samples in a single experiment. The experiment was repeated five times with similar results (poly-L-histidine-treated streptococci without GO, $\bullet-\bullet$; control streptococci $+\mathrm{GO}, \mathbf{\Delta - \Delta}$ poly-L-histidine-treated streptococci + GO, n- ; GO alone, O; poly-L-histidine-treated streptococci (0.4 OD units) + GO + 50 $\mu \mathrm{g}$ of trypan blue $\Delta$; poly-L-histidine-treated streptococci (0.4 OD units) $+\mathrm{GO}+1800 \mathrm{units} / \mathrm{ml}$ catalase, $\square$ ).

seen from the same figure that the poly-L-histidinetreated cells produced a greater amount of injury (and at a lower bacterial concentration) than untreated bacteria. Further, it can be seen that just as catalase and trypan blue inhibited injury mediated by combinations of soluble streptolysin S and GO, the same two agents completely inhibited the synergistic injury resulting from combinations of intact group A streptococci and $\mathrm{H}_{2} \mathrm{O}_{2}$ (Fig. 1). As an additional control, 50 $\mathrm{mM}$ 3-amino-1,4 triazol (aminotriazol) was incubated with $1800 \mathrm{U}$ of catalase for $2 \mathrm{~h}$ at room temperature. Following this, the treated catalase no longer interfered with $\mathrm{H}_{2} \mathrm{O}_{2}$ production from $\mathrm{GO}$ as indicated by the Thurman reaction. The aminotriazol-treated catalase also failed to interfere with the synergistic killing of endothelial cells by $\mathrm{H}_{2} \mathrm{O}_{2}$ and group A streptococcal cells (less than $5 \%$ inhibition; data not shown).

\section{DISCUSSION}

Inflammatory lesions contain large numbers of effector cells and mediators, and it is very difficult to identify the contribution of any single inflammatory mediator to the overall generation of the lesion. It is clear that both reactive oxygen metabolites ${ }^{6-9}$ and proteolytic enzymes ${ }^{3,4,14,15}$ derived from inflammatory cells play important roles. It was at one time (naively) thought that oxygen radicals were responsible for cell killing while proteolytic enzymes were the direct cause of the structural tissue breakdown seen in a number of inflammatory processes. It is now understood, however, that even with these two groups of inflammatory mediators, the situation is complex. Both reactive oxygen metabolites and proteolytic enzymes can lethally injure cells by their independent actions. ${ }^{10-13,30,31}$ Further, they can interact together to produce lethal injury to cells that would not otherwise be killed. ${ }^{21,23,32}$ In a similar manner, proteolytic enzymes and reactive oxygen metabolites can interact to enhance damage to structural tissue components. ${ }^{33}$

While interactions between proteolytic enzymes and oxygen radicals have been studied most thoroughly, recent work from our own laboratory has shown that a number of other factors can also interact with reactive oxygen metabolites to injure cells. ${ }^{22-24}$ Among these are solubilized components of group A streptococcal bacteria, including the hemolysin, streptolysin S. Streptolysin S acts at the level of the target endothelial cell to produce lethal injury to cells in the presence of a concentration of $\mathrm{H}_{2} \mathrm{O}_{2}$ that would otherwise not produce lethal injury. The ability of group A streptococcal products to interact with $\mathrm{H}_{2} \mathrm{O}_{2}$ to induce endothelial cell injury has led us to speculate that poststreptococcal sequelae, including rheumatic heart disease and glomerulonephritis, may be the result of exaggerated inflammatory injury to the host. Perhaps streptococcal cells growing on the valves of the heart or lodged in the glomeruli of the 
kidney are attacked by circulating neutrophils. In the presence of high concentrations of bacterial products, leukocytes may not only destroy the bacterial cells but concomitantly damage the vascular lining cells at the colonized site.

The data from the present study lend further support for this idea. Here we have shown that live group A streptococcal organisms are not directly cytotoxic to endothelial cells in culture under the conditions utilized. However, when sedimented directly onto a monolayer of endothelial cells, the intact bacterial cells are capable of the same interactions with neutrophil products $\left(\mathrm{H}_{2} \mathrm{O}_{2}\right.$ alone or in combination with elastase) as solubilized streptococcal products. Demonstration that intact cells are capable of eliciting the same responses as solubilized bacterial products is important, we believe, since it is difficult to visualize how solubilized bacterial products released into the circulation could be concentrated enough at a particular site to provoke injury.

At present we do not know what factors associated with the intact microbial cells are responsible for interacting with $\mathrm{H}_{2} \mathrm{O}_{2}$ to produce endothelial cell injury. It is tempting to speculate that the same agent that works in solubilized form (i.e., streptolysin $\mathrm{S}$ ) is also responsible for the effects observed with intact cells. However, this is yet to be proven. The only evidence at present suggesting the possible involvement of streptolysin $\mathrm{S}$ is the finding that trypan blue, a potent streptolysin $\mathrm{S}$ inhibitor, ${ }^{29}$ prevented endothelial cell injury induced by GO in combination with either soluble streptolysin S or intact streptococcal cells. Further evidence that the cell-bound hemolysin might be the cytotoxic factor associated with streptococci came from our earlier observations that a streptococcal mu$\operatorname{tant}(\mathrm{C}-203 \mathrm{U})$, which elaborates streptolysin 0 but not the cell-bound hemolysin or the soluble streptolysin $S$, failed either to hemolyze red blood cells or kill tumor cells by contact. ${ }^{27}$ Further studies will need to be done to confirm that cell-bound streptolysin $\mathrm{S}$ is responsible for the endothelial cell injury seen in this model. Regardless of the outcome, the finding that intact group A streptococci can synergize with products of inflammatory cells to produce injury to vascular lining cells provides insight into a possible mechanism for the sequelae which often follow primary infection with this agent.

Acknowledgement-This study was supported in part by ACS grant IM-432 and by a grant from Dr. S. M. Robbins of Cleveland, Ohio, USA.

\section{REFERENCES}

1. Brigham, K. L. Mechanisms of lung injury. Clin. Chest Med. 3:9-16; 1982.
2. Tate, R. M.; Repine, J. E. Neutrophils and the adult respiratory distress syndrome. Am. Rev. Respir. Dis. 125:552-560; 1983.

3. Hennette, J. C.; Tedwell, R. R.; Geratz, J. D.; Bing, D. H.; Folks, R. J. Amelioration of immune complex-mediated glomerulonephritis by synthetic protease inhibitors. $\mathrm{Am}$. J. Pathol. 127:499-506; 1987.

4. Hawkins, G.; Cochrane, C. G. Glomerular basement membrane damage in immunological glomerulonephritis. $J$. Immunol. 14:665-681; 1968.

5. Wong, P. S.; Travis, J. Isolation and properties of oxidized alpha-1 proteinase inhibitor from human rheumatoid synovial fluid. Biochem. Biophys. Res. Comm. 96:1449-1454; 1980.

6. Johnson, K. J.; Ward, P. A. Acute immunologic pulmonary alveolitis. J. Clin. Invest. 54:349-357; 1974.

7. Johnson, K. J.; Ward, P. A. Role of oxygen metabolites in immune complex injury of lung. J. Immunol. 126:2365-2369; 1981.

8. Johnson, K. J.; Ward, P. A.; Kunkel, R. G.; Wilson, B. S. Mediation of IgA induced lung injury in the rat. Role of macrophages and reactive oxygen products. Lab. Invest. 54:499-506; 1986.

9. Fligiel, S. E. G.; Ward, P. A.; Johnson, K. J.; Till, G. O. Evidence for a role of hydroxyl radical in immune complex-induced vasculitis. Am. J. Pathol. 115:375-383; 1984.

10. Sacks, T.; Moldow, C. F.; Craddock, P. R.; Bowers, T. K.; Ja$\mathrm{cob}, \mathrm{H}$. A. Oxygen radicals mediate endothelial damage by complement-stimulated granulocytes. An in vitro model of immune complex vasculitis. J. Clin. Invest. 61:1161-1167; 1978.

11. Weiss, S. J.; Young, J.; LoBuglio, A. F.; Slivka, A.; Nimeh, N. F. Role of hydrogen peroxide in neutrophil-mediated destruction of cultured endothelial cells. J. Clin. Invest. 68:714$720 ; 1981$.

12. Martin, W. J. Neutrophils kill pulmonary endothelial cells by a hydrogen peroxide-dependent pathway. An in vitro model of neutrophil-mediated lung injury. Am. Rev. Respir. Dis. 130:209-213; 1984.

13. Varani, J.; Fligiel, S. E. G.; Till, G. O.; Kunkel, R. G.; Ryan, U.S.; Ward, P. A. Pulmonary endothelial cell killing by human neutrophils: Possible involvement of hydroxyl radical. $L a b$. Invest. 53:656-663; 1985.

14. Spitznagel, J. K. Non-oxidative anti-microbial reactions of leukocytes. In: Snyderman, R., ed. Contemporary topics in immunobiology. Vol. 14. New York: Plenum Press; 1984:283-343.

15. Elsbach, P.; Weiss, J. Phagocytic cells: Oxygen independent anti-microbial systems. In: Gallin, J. T.; Goldstein, I. M.; Snyderman, R., eds. Inflammation: Basic principles and clinical correlates. New York: Raven Press; 1988:449-453.

16. Warren, J. S.; Yabroff, K. R.; Remick, D. G.; Kunkel, S. L.; Chensue, S. W.; Kunkel, R. G.; Johnson, K. J.; Ward, P. A. Tumor necrosis factor participates in the pathogenesis of acute immune complex alveolitis in the rat. J. Clin. Invest. 84:1873$1882 ; 1989$

17. Warren, J. S. Intrapulmonary interleukin-1 mediates acute immune complex alveolitis in the rat. Biochem. Biophys. Res. Comm. 175:604-610; 1991.

18. Ginsburg, I. Streptococcal enzymes and virulence. In: Holder, I. A., ed. Bacterial enzymes and virulence. Boca Raton, FL: CRC Press, 1985:12-114.

19. Ofek, I.; Zafriri, D.; Goldhart, J.; Eisenstein, B. I. Inability of toxin inhibitors to neutralize enhanced toxicity caused by bacteria adherent to tissue culture cells. Infect. Immun. 58:3737$3742 ; 1990$.

20. Rothstein, J. L.; Schreiber, H. Synergy between tumor necrosis factor and bacterial products causes hemorrhagic necrosis and lethal shock in normal mice. Proc. Nat. Acad. Sci. USA 85:607-611; 1988 .

21. Varani, J.; Ginsburg, I.; Schuger, L.; Gibbs, D.; Bromberg, J.; Johnson, K. J.; Ryan, U. S.; Ward, P. A. Endothelial cell killing by neutrophils. Synergistic interaction of oxygen products and proteases. Am. J. Pathol. 135:435-438; 1989.

22. Ginsburg, I.; Misgav, R.; Pinson, A.; Varani, J.; Ward, P. A.; Kohen, R. Synergism among oxidants, proteinases, phospholipases, microbial hemolysins, cationic proteins and cytokines: 
A possible major cause of cell and tissue injury in inflammation (a working hypothesis). Inflammation 16:512-538; 1992.

23. Ginsburg, I.; Gibbs, D. F.; Schuger, L.; Johnson, K. J.; Ryan, U. S.; Ward, P. A.; Varani, J. Vascular endothelial cell killing by combinations of membrane-active agents and hydrogen peroxide. Free Radic. Biol. Med. 7:369-376; 1988.

24. Varani, J.; Bendelow, M. J.; Sealy, D. E.; Kunkel, S. L.; Gannon, D. E.; Ryan, U. S.; Ward, P. A. Tumor necrosis factor enhances susceptibility of vascular endothelial cells to neutrophil-mediated killing. Lab. Invest. 59:292-295; 1988.

25. Phan, S. H.; Gannon, D. E.; Varani, J.; Ryan, U. S.; Ward, P. A. Xanthine oxidase activity in rat pulmonary artery endothelial cells and its alteration by activated neutrophils. $\mathrm{Am} . J$. Pathol. 134:1201-1212; 1989.

26. Ginsburg, I. Action of streptococcal hemolysins and proteolytic enzymes on Ehrlich ascites tumor cells. Brit. J. Exp. Path. 40:417-423; 1959.

27. Ginsburg, I.; Harris, T. N. Oxygen-stable hemolysins of group A streptococci IV. Studies on the mechanisms of lysis by cellbound hemolysin of red blood cells and Ehrlich ascites tumor cells. J. Exp. Med. 121:647-656; 1965.

28. Thurman, R. G.; Leyland, H. G.; Schultz, R. Hepatic micro- somal ethanol oxidation, hydrogen peroxide formation and the role of catalase. Eur. J. Biochem. 25:420-430; 1972.

29. Ginsburg, I.; Bentwich, Z.; Harris, T. N. Oxygen-stable hemolysins of group A streptococci. III. The relationship of the cell bound hemolysin to streptolysin S. J. Exp. Med. 121:635-645; 1965.

30. Pontremoli, S.; Melloni, E.; Michetti, M.; Sacco, O.; Sparatore, B.; Salamino, F.; Damiani, G.; Horecker, B. L. Cytolytic effects of neutrophils: Role for a membrane-bound neutral protease. Proc. Natl. Acad. Sci. USA 83:1685-1689; 1986.

31. Smedly, L. A.; Tonneson, M. G.; Sandhaus, R. A.; Haslett, C.; Guthrie, L. A.; Johnson, R. B.; Henson, P. M.; Worthen, G. S. Neutrophil-mediated injury to endothelial cells: Enhancement by endotoxin and essential role of neutrophil elastase. J. Clin. Invest. 77:1233-1243; 1986.

32. Rodell, T. C.; Cheronis, J. C.; Ohnemus, C. L.; Piermattei, D. J.; Repine, J.E. Xanthine oxidase mediates elastase induced injury to isolated lungs and endothelium. J. Appl. Physiol. 63:2159-2164; 1987.

33. Fligiel, S. E. G.; Lee, E. C.; McCoy, J. P.; Johnson, K. J.; Ward, P. A.; Varani, J. Protein degradation following treatment with hydrogen peroxide. Am. J. Pathol. 115:418-425; 1984. 